\title{
The Canadian
}

Journal of Linguistics

La Revue canadienne

de Linguistique

FALL/AUTOMNE 1966-12:1 


\section{Canadian Linguistic Association Association canadienne de Linguistique}

OFFICERS / BUREAU

President/Président Past President/

Président sortant

Vice-President / Vice-Président Secretary/Secrétaire Treasurer/Trésorier

Members of the Executive/ Membres du Conseil

Editor/Rédacteur Associate Editor/

Rédacteur adjoint Book Review Editor/ Rédacteur des Comptes rendus
J. DARBELNET, Laval

M. H. SCARGILL, Univ. of Victoria w. s. Avis, Royal Military College w. s. Avis, Royal Military College H. R. Wilson, Royal Military College

W. F. MACKEY, Laval

R. J. GREGG, U.B.C.

J. W. WEVERS, Toronto

E. N. BURSTYNSKY, Toronto

G. L. BURSILL-HALL, Simon Fraser

The canadian Journal of Linguistics is the official publication of the Association. Annual dues of four dollars, which include subscription to the Journal, are payable to the Treasurer. Available back issues may also be ordered from the Treasurer.

Manuscripts in English or French may be sent to the Editor, Prof. J. W. Wevers, Dept. of Near Eastern Studies, University of Toronto, Toronto 5, Canada. A Style Sheet should be secured from the Editor before the final manuscript is typed. Books for review should be sent to the Book Review Editor.

La revue canadienne de linguistique est l'organe officiel de l'Association canadienne de Linguistique. Le montant de la cotisation, abonnement compris, est de quatre dollars et doit être versé au Trésorier. Les manuscrits et toute correspondance relative à la rédaction de la Revue doivent être envoyés au Rédacteur ou au Rédacteur adjoint. Les collaborateurs sont priés de demander le protocole de la Revue avant de rédiger la version définitive de leur manuscrit. Les livres pour recensions et les comptes rendus sont à envoyer au Rédacteur des comptes rendus.

Copyright 1966 by the Canadian Linguistic Association

Published by the University of Toronto Press

The canadian journal or linguistics continues the journal or the CANADIAN LINGUISTIC ASSOCIATION.

La REVUE CANADIENNE DE LINGUISTIQUE fait suite à la REVUE DE L'ASSOCIATION CANADIENNE DE LINGUISTIQUE. 


\section{Contents}

THE CANADIAN JOURNAL OF LINGUISTICS, FALL 1966, 12:1

\section{Sommaire}

La Revue Canadienne De linguistique, AUtomne 1966, $12: 1$

Editorial, 3

Report of the Annual Meeting 1966, 4

c. DEAN, Some consonantal elements in Northern English dialects, 9

G. H. SCHAARSCHMIDT, Quasi-direct discourse: style or grammar? 24

B. BRAINERD, Two grammars for Chinese number names, 33

M. I. SURDUCKI, English loanwords in the Serbo-Croatian immigrant press, 52

Reviews/Comptes rendus

P. W. DAVIS, 64 